DOI: $10.35757 / \mathrm{SM} .2018 .71 .2 .10$

ENERGETYKA

\title{
ANNA KUCHARSKA
}

Uniwersytet Jagielloński w Krakowie

\section{Rola Niemiec w Unii Europejskiej w kontekście budowy unii energetycznej}

\section{The Energy Union and the Role of Germany in the European Union}

The energy union is a relatively new concept, which indicates on the practical implementation of energy security in the European Union. Energy union meets a general agreement on its necessity, but discrepancies between countries arise while trying to create a more detailed definition of this concept. National interests of individual countries appear when the objectives of the energy union are to be defined. The influence of the European Union on the energy policy of the member states is significant, but also the impact of individual members on the Union itself has to be emphasized. The largest and most powerful member states, such as Germany, have a particular role in the EU and the ability to influence it. From this perspective, it is worth to analyze the role of Germany in the European Union taking into account their attitude to the energy union as well as to follow in this approach the evolution of this concept. It is important to note that the Energy Union, which refers in a broader perspective to such a crucial issue as the shape of energy supplies to the European Union, is one of the key elements affecting regional international relations.

Keywords: energy union, energy transition, European Union, Germany.

\section{Wstęp}

Unia energetyczna jest koncepcją stosunkowo nową. Co do zasady, panuje wobec niej powszechna zgoda w Unii Europejskiej (UE). Rozbieżności między państwami pojawiają się przy próbach stworzenia bardziej szczegółowej definicji tego pojęcia oraz jej celów. Zagadnienia związane z unią energetyczną znajdują się w centrum uwagi nie tylko środowiska eksperckiego i naukowego, ale także szeroko rozumianej opinii publicznej, a przede wszystkim decydentów politycznych. Wpływ Unii Europejskiej na politykę energetyczną państw członkowskich jest znaczący, niemniej podkreśla się także odziaływanie poszczególnych 
członków na samą Unię. Szczególne znaczenie w oddziaływaniu na UE mają największe i najsilniejsze państwa członkowskie, takie jak Niemcy. Z tej perspektywy warto przeanalizować rolę Niemiec w Unii Europejskiej w kontekście ich stosunku do unii energetycznej i prześledzić w tym ujęciu ewolucję definicji tej koncepcji. Należy szczególnie mieć na uwadze, że unia energetyczna, odnosząca się w szerszej perspektywie do tak istotnego zagadnienia, jak kształt dostaw energii do Unii Europejskiej, jest jednym z kluczowych elementów wpływających na stosunki międzynarodowe w regionie.

Niemcy są największym konsumentem energii $\mathrm{w}$ Europie $^{1}$ i należą do członków Unii o najwyższym udziale w imporcie gazu ziemnego, wynoszącym ponad $20 \%$ importu netto UE. Zaliczają się też do największych importerów ropy naftowej pochodzącej z Rosji, w której ich udział wynosi ok. $10-20 \%{ }^{2}$. Udział Niemiec w ogólnym zużyciu energii w UE wynosi ok. 19\%, podobnie udział w produkcji energii elektrycznej stanowi ok. 19\%. Zajmują drugie miejsce wśród największych europejskich producentów węgla $^{3}$. Duże znaczenie tego państwa w kontekście energetyki wynika także z jego centralnego położenia geograficznego w Europie, dzięki czemu znajduje się ono w centrum europejskich sieci przesyłowych ${ }^{4}$. Istotny jest tu również dostęp do morza, który rozszerza możliwości handlowe.

Położenie geograficzne Niemiec ma dwojakie znaczenie dla UE. Po pierwsze, państwo to może stanowić korytarz energetyczny dla przesyłu energii przez swoje terytorium. Podobną rolę odgrywa jednak wiele krajów położonych w centrum Europy. Po drugie, produkując wysokie wolumeny energii, Niemcy mogą stanowić europejskie centrum energetyczne. Daje się zauważyć, że dążą raczej do uzyskania pozycji lidera na polu energetycznym niż jedynie państwa tranzytowego dla przesyłu energii. Takie stwierdzenie znajduje uzasadnienie w dwóch kierunkach podejmowanych przez to państwa działań. W ramach pierwszego należy podkreślić silny nacisk na rozbudowę instalacji odnawialnych źródeł energii (OZE) i zwiększaniu krajowej produkcji energii elektrycznej. Wiążą się z tym bezpośrednio także inne obszary m.in.: rozwój szeroko rozumianej infrastruktury, innowacyjne technologie czy nowoczesne

1 A.Łada, M. Skłodowska, M. Szczepanik, Ł. Wenerski, Unia energetyczna z perspektywyFrancji, Niemiec, Polski i Wielkiej Brytanii, Instytut Spraw Publicznych, Warszawa 2015, s. 57.

2 EU Imports of Energy Products - Recent Developments, Eurostat, October 2017, http:// ec.europa.eu/eurostat/statistics-explained/pdfscache/46126.pdf, s. 8 (dostęp: 25.4.2018).

3 B. Molo, Bezpieczeństwo zaopatrzenia energetycznego Niemiec w kontekście unii energetycznej Unii Europejskiej, „Bezpieczeństwo - Teoria i Praktyka” 2016 nr 1, KSW, Kraków 2016, s. 54.

4 Ibidem. 
rozwiązania. Dysponując dużą mocą wytwórczą energii elektrycznej, Niemcy mogą jej nadmiar eksportować za granicę, podobnie jak powiązane z nimi know-how. W przypadku współczesnego modelu energetyki, rozumianego jako łańcuch wartości rozproszonego procesu produkcji, inteligentnego przesyłu i magazynowania oraz konsumpcji energii elektrycznej, zdobywanie przewag gospodarczych opiera się na innowacyjności rozwiązań, ich kompleksowości i skutecznym łączeniu elementów systemu.

Drugi kierunek działań stanowi położenie punktu ciężkości na gaz ziemny. Wiąże się z tym zwiększanie zarówno liczby, jak i pojemości magazynów energii (najczęściej magazynów gazu ze względu na bieżące możliwości technologiczne), które zabezpieczają jako swoisty back-up krajowe zapotrzebowanie na energię w razie niedostatecznej produkcji ze źródeł odnawialnych. Na tym polu Niemcy poszły o krok dalej, dzięki połączeniu gazowemu z Federacją Rosyjską, tworząc korytarz gazowy zapewniający surowiec nie tylko dla Niemiec, ale też dla pozostałych państw członkowskich UE. Należy podkreślić, że zapotrzebowanie energetyczne na gaz jest wzmacniane poprzez promowanie przez Niemcy prośrodowiskowej i zeroemisyjnej energetyki, przy jednoczesnej dewaluacji rozwiązań jądrowych z wykorzystaniem w tym celu awarii w Fukushimie. $\mathrm{W}$ ten sposób dostępne rozwiązania $\mathrm{w}$ ramach produkcji energii jednoznacznie ograniczają akceptowalne źródła energii do tych tzw. odnawialnych. Tym samym gaz ziemny pozostaje jedynym paliwem konwencjonalnym, któremu przyznaje się miejsce we współcześnie promowanym modelu energetyki.

Wobec powyższych uwag, w interesie Niemiec leży „eksport” polityki określanej jako przełom energetyczny (Energiewende), tj. transformacji sektora energetycznego w postaci rezygnacji z konwencjonalnych nośników energii na rzecz źródeł odnawialnych w produkcji energii (elektrycznej, cieplnej i klimatyzacji), przy zachowaniu dbałości o ochronę środowiska i klimatu oraz opłacalności ekonomicznej ${ }^{5}$. Tak rozumiana transformacja stanowi w istocie politykę przemodelowania sfery społeczno-gospodarczej. Zamiarem Niemiec jest przekształcenie systemu energetycznego do 2050 r. Fakt, że unia energetyczna ma temu służyć, jest wprost przedstawiany w analizach niemieckich ośrodków badawczych i dokumentach rządowych, w których omawiane jest to zagadnienie ${ }^{6}$.

5 V. Wittpahl, Digitalisierung. Bildung - Technik - Innovation, iit-Themenband, Springer, Berlin 2017, s. 141.

6 K. Umpfenbach, Nach der Bundestagswahl: Worauf es für die deutsche Politik beim Energiepaket der EU ankommt, Heinrich-Böll-Stiftung, Berlin, Oktorber 2017, s. 5 www. boell.de/sites/default/files/nach_der_bundestagswahl-energiepaket_eu.pdf?dimensionl=division_eu, (dostęp: 5.06.2018). 
Obecnie obserwuje się, że polityka transformacji energetycznej stała się światowym trendem, realizowanym w wielu państwach, oraz że jest promowana jako ważny element walki z ubóstwem energetycznym, jak również podnoszenia bezpieczeństwa energetycznego. Należy podkreślić, że opór państw wobec polityki transformacji energetycznej spotyka się ze swoistym szantażem politycznym z wykorzystaniem argumentów ochrony środowiska i zmian klimatu. Analogiczny dylemat (tj. kwestia narzucania określonych rozwiązań systemowych) pojawia się w kontekście np. demokratyzacji państw postsowieckich w regionie Morza Kaspijskiego. O ile w latach 70. XX w. uważano demokrację za jedyne słuszne i uniwersalne rozwiązanie w skali globalnej, o tyle w ciągu ostatnich dwudziestu lat zaczęto podważać tę tezę w literaturze naukowej, dostrzegając specyfikę i zróżnicowanie państw postsowieckich w stosunku do tzw. demokracji zachodnich.

Ograniczając się do obszaru Europy, należy zauważyć, że agresywna polityka transformacji energetycznej może doprowadzić do zaburzenia systemów energetycznych w niektórych państwach. Na przykład w Polsce brakuje funduszy na utworzenie magazynów energii o wystarczającej pojemności, a jednoczesna rezygnacja z krajowego źródła energii, jakim jest węgiel, może doprowadzić do wzrostu uzależnienia od importu energii z zewnątrz. Innym przykładem może być Szwajcaria, która z przyczyn geologicznych ma ograniczone możliwości magazynowania energii, dodatkowo ukształtowanie terenu w znaczący sposób utrudnia rozbudowę na szeroką skalę instalacji $\mathrm{OZE}^{7}$. Rezygnacja Szwajcarii z posiadania elektrowni jądrowych stawia to państwo, o wysokim stopniu zużycia energii, w sytuacji poważnych wyzwań związanych z kwestią przyszłego pokrycia zapotrzebowania na energię. Polityka transformacji energetycznej może zatem okazać się platformą do tworzenia międzynarodowych zależności państw o słabszej pozycji, pod względem finansowym lub uwarunkowań naturalnych, wobec państw, które dzięki sprzyjającym okolicznościom wypracowały dominację na tym polu. Zwrócenie uwagi na ten problem ma znaczenie dla dalszych rozważań na temat koncepcji budowy unii energetycznej.

7 Więcej na ten temat zob. A. Kucharska, Energy Transition in Switzerland, w: M. Ruszel, T. Młynarski, A. Szurlej (red.), Energy Policy Transition: the Perspective of Different States, Ignacy Łukasiewicz Energy Policy Institute, Rzeszów 2017, s. 197-211. 


\section{Perspektywa teoretyczna}

Do pytań, jakie trzeba postawić w świetle powyższych rozważań, należy kwestia faktycznej kooperacji w kwestii energetyki w ramach UE. Czy działania Niemiec rzeczywiście wskazują na zgodę, że celem unii energetycznej jest tworzenie europejskiej wspólnoty współdziałającej na rzecz bezpieczeństwa energetycznego? Czy też może jest to element polityki efektywnego wykorzystania przewag terytorialnych, finansowych i technologicznych w celu realizacji własnych interesów narodowych oraz rozszerzania wpływów politycznych na inne państwa poprzez redefiniowanie ich struktury społeczno-gospodarczej? W pytaniach o współpracę lub konkurencyjność (w celu zdobywania przewag) między państwami zderzają się dwie teorie stosunków międzynarodowych: liberalna i realizmu.

Zgodnie z podejściem liberalnym, stosunki między państwami charakteryzuje współpraca, ponieważ stanowi ona skuteczny środek do osiągania bogactwa. W liberalizmie rzeczywistość międzynarodowa jest postrzegana pokojowo i opiera się na założeniu istnienia harmonii interesów społeczeństw i państw. Ta harmonia interesów dotyczy przede wszystkim sfery interesów gospodarczych państw. Rzeczywisty interes państw polega na niczym nieograniczanym rozwoju więzi ekonomicznych, wolnym handlu i wzajemnej współpracy gospodarczej ${ }^{8}$. Funkcja handlu międzynarodowego, np. energią, technologiami z obszaru OZE, służy nie tylko korzyściom ekonomicznym, jakie zyskują obie strony, ale też rozwiązywaniu czy zapobieganiu konfliktom, które się żadnej ze stron nie opłacają

Odmiennie do liberalizmu, teoria realizmu przyjmuje, że podmiotem stosunków międzynarodowych jest państwo dążące do wzmocnienia suwerenności, rozumianej jako niezależność od czynników zewnętrznych. Państwo jest unitarne, co oznacza, że rząd jest jedynym wyrazicielem interesów państwa. Relacje między państwami zachodzą więc podobnie jak między rywalizującymi ze sobą osobami i stanowią reakcje na zachowanie innego państwa. W zapewnianiu bezpieczeństwa państwo stanowi główny i jedyny podmiot.

8 E. Haliżak, Liberalna teoria polityki zagranicznej, w: E. Haliżak, R. Ożarowski, A. Wróbel (red.), Liberalizm i neoliberalizm w badaniu polityki zagranicznej państwa i gospodarki światowej, Rambler staraniem Polskiego Towarzystwa Stosunków Międzynarodowych, Warszawa 2016, s. 17-20.

9 E. Haliżak, Ekonomiczny wymiar bezpieczeństwa narodowego i międzynarodowego, w: D.B. Bobrow, E. Haliżak, R. Zięba (red.), Bezpieczeństwo narodowe i międzynarodowe u schytku XX wieku, Wydawnictwo Naukowe „Scholar”, Warszawa 1997, s. 80-81. 
Relacje międzynarodowe są przy tym postrzegane według paradygmatu siły. Składają się na nią czynniki wymierne, jak liczba ludności, położenie geograficzne, bogactwa naturalne, wielkość przemysłu, ale także niewymierne, jak jakość przywództwa i charakter narodowy ${ }^{10}$.

Zgodnie z teorią liberalną, za pomocą której najczęściej analizuje się politykę transformacji energetycznej czy unii energetycznej, obie te koncepcje stanowią naturalną kolej rzeczy w obliczu zmieniającego się świata i wyzwań cywilizacyjnych, takich jak ochrona środowiska i klimatu, oraz rozwoju technologii, które umożliwiają wykorzystanie naturalnych i odnawialnych źródeł energii. Tymczasem $\mathrm{w}$ świetle teorii realizmu ten sam proces ujęty jest $\mathrm{z}$ innej perspektywy - wskazuje na adaptację nowych instrumentów, $w$ formie koncepcji energetyczno-klimatycznej i związanych z nią innowacyjnych rozwiązań technologicznych, do realizacji starych celów, tj. walki o władzę i wpływy polityczne.

W odniesieniu do wymienionych teorii i uwzględniając ambitne cele Niemiec w kwestii polityki energetycznej, można stwierdzić, że państwu temu zależy nie tyle na współpracy wielu krajów w zakresie wspólnej budowy bezpieczeństwa energetycznego, ile raczej na partykularnych interesach jednego państwa w zdobywaniu przewagi gospodarczej i rozszerzaniu swoich wpływów politycznych. Stwierdzenie to uzasadniane jest przez niemieckie podejście, zgodnie z którym niezależnie od uwarunkowań, w jakich znajdują się różne państwa, wszystkie powinny w równym stopniu realizować tę samą politykę energetyczną. W tym ujęciu działanie Niemiec z wykorzystaniem energetyki jako narzędzia - niezwykle istotnej ze względu na znaczenie energii we współczesnym świecie wpisuje się w geoekonomiczny charakter budowy relacji międzynarodowych.

Twórcą teorii geoekonomii był Edward Luttwak, który zauważył, że we współczesnym świecie metody handlowe zastępują metody militarne. Rośnie znaczenie kapitału, inwestycji i technologicznych innowacji, natomiast siła militarna jest stopniowo dewaluowana. Rywalizacja między państwami przenosi się na pole ekonomii wraz z jej założeniami i środkami, a wojny zastępowane są ekspansją gospodarczą ${ }^{11}$. $Z$ kolei dążenie państw do budowy potęgi gospodarczej przekłada się na wpływy polityczne, stąd system międzynarodowy staje się systemem międzynarodowej ekonomii ${ }^{12}$. Niemniej uważa się, że państwa dążą do zapewnienia jak największej części swojej populacji

10 K. Żukrowska, M. Grącik (red.), Bezpieczeństwo międzynarodowe. Teoria i praktyka, Szkoła Główna Handlowa, Warszawa 2006, s. 47-48.

11 R. Ulatowski, Geoekonomia surowców energetycznych, Rambler, Warszawa 2014, s. 28.

12 S. Bieleń, Erozja monocentryzmu w stosunkach międzynarodowych, w: P. Eberhardt (red.), Studia nad geopolityka XX wieku, „Prace Geograficzne” Warszawa 2013, nr 242, s. 104. 
możliwie najlepszych warunków do życia, co czynią m.in. poprzez politykę handlową, wspieranie rozwoju nowoczesnych technologii, edukacji, rozwoju infrastruktury. Państwa jednocześnie konkurują i współpracują ze sobą ${ }^{13}$, co dobrze odzwierciedla działania Niemiec w Unii Europejskiej oraz ich relacje handlowe gazem ziemnym z Federacją Rosyjską. Geoekonomia w znacznym stopniu znajduje zastosowanie w analizach dotyczących energetyki. Dzieje się tak z powodu specyfiki tego sektora, który jako gałąź gospodarcza niewątpliwie ma wymiar ekonomiczny. Natomiast jego znaczenie dla funkcjonowania współczesnych społeczeństw oraz fakt, że państwa pozostają najważniejszym aktorem na rynkach energetycznych, nadają temu sektorowi charakteru politycznego ${ }^{14}$.

\section{Geneza koncepcji unii energetycznej}

Koncepcja unii energetycznej jest dość młoda, została zainspirowana pierwotnie przez Jacques'a Delorsa i Jerzego Buzka w inicjatywie stworzenia Europejskiej Wspólnoty Energetycznej w 2010 r. ${ }^{15}$ Faktycznie jednak początki unii energetycznej kojarzone są z osobą byłego premiera Donalda Tuska, który w 2014 r. wysunął propozycję jej utworzenia. Bezpośrednim bodźcem do jej opracowania był rosyjsko-ukraiński kryzys, którego skutkiem było ograniczenie dostaw gazu ziemnego na Ukrainę. Ze względu na funkcję tranzytową tego państwa w przesyle surowca, ograniczenie to uderzyło także w inne kraje. Stąd też podstawą koncepcji unii energetycznej i jej głównym założeniem było wzmocnienie bezpieczeństwa energetycznego i surowcowego w celu zapewnienia bezpieczeństwa dostaw wszystkim państw Unii Europejskiej. Pomysł stworzenia unii energetycznej został w ogólnym zarysie pozytywnie przyjęty na forum UE.

Unia Europejska jest największym na świecie importerem nośników energii. Spowodowane jest to dużym zapotrzebowaniem energetycznym oraz niewystarczającą ilością własnych złóż surowców energetycznych ${ }^{16}$. Pod tym względem największy udział ma ropa naftowa (69\%), potem gaz ziemny, którego udział w całości importu wynosi $20 \%$. W obu przypadkach większość importu pochodzi z Rosji i stanowi odpowiednio 30,9\% (ropa naftowa) oraz

13 R. Ulatowski, Geoekonomia..., s. 31.

14 Ibidem, s. 25-26.

15 S. Andoura, J.A. Vinois, From the European Energy Community to the Energy Union. A Policy Proposal for the Short and the Long Term, „Studies \& Reports” 2015, nr 107, Jacques Delors Institute, s. 121.

16 A. Łada, M. Skłodowska, M. Szczepanik, Ł. Wenerski, Unia energetyczna..., s. 11. 
$37,4 \%$ (gaz ziemny) ${ }^{17}$. Unijna zależność od importu nośników energii stawia zagadnienie bezpieczeństwa energetycznego wysoko na liście priorytetów. Samo pojęcie bezpieczeństwa energetycznego jest wielowymiarowe i odnosi się do bezpieczeństwa narodowego, stosunków międzynarodowych, polityki środowiskowej, rozwoju ekonomicznego, a także bezpieczeństwa ludzkiego, włączając $w$ to zarówno wewnętrzne, jak i zewnętrzne działania ${ }^{18}$. W najprostszym ujęciu bezpieczeństwo energetyczne obejmuje dostępność energii rozpatrywaną w aspekcie ekonomicznej opłacalności oraz gwarancji niezawodności dostaw. Zgodnie z tą definicją, stopień bezpieczeństwa energetycznego określają zmiany wskaźników dywersyfikacji źródeł energii, samowystarczalności paliwowej oraz zależności importowej, która przedstawia stosunek importu netto do całkowitego zużycia energii pierwotnej ${ }^{19}$.

Według projektu Donalda Tuska, unia energetyczna miała opierać się na mechanizmie solidarności w razie wystąpienia kolejnych kryzysów w dostawach gazu ziemnego, czemu towarzyszyć miała rozbudowa potrzebnej infrastruktury przesyłowej na obszarze UE. Koncepcja zakładała więc zwiększenie środków na finansowanie budowy sieci przesyłowych. Projekt przewidywał także wprowadzenie systemu wspólnych zakupów gazu dla wszystkich państw należących do UE, aby z jednej strony zagwarantować równą stawkę cenową na obszarze Unii, a z drugiej wzmocnić pozycję negocjacyjną przy zawieraniu umów z Rosją na zakup surowca. Wobec tego zagadnienia sprzeciw zgłosiły Niemcy, uzasadniając to naruszeniem zasad wolnego rynku i konkurencyjności $i^{20}$, nie znalazło się ono także w późniejszych propozycjach Komisji Europejskiej, chociaż dopuściła ona możliwość wspólnych zakupów gazu ziemnego. Ponadto założeniem unii energetycznej był wzrost stopnia dywersyfikacji dostaw gazu ziemnego do UE w połączeniu ze wspieraniem wydobycia gazu łupkowego ${ }^{21}$.

W skutek debat na forum unijnym koncepcja unii energetycznej została rozszerzona o dodatkowe elementy, współgrające z innym współczesnym trendem kształtującym rzeczywistość energetyczną, a mianowicie transformacją

17 EU Imports of Energy..., s. 1.

18 M. Kaczmarski, Bezpieczeństwo energetyczne Unii Europejskiej, Wydawnictwa Akademickie i Profesjonalne, Warszawa 2010, s. 14.

19 J. Mazurkiewicz, Bezpieczeństwo energetyczne Polski, „Polityka Energetyczna” 2008, t. 11, z. 1, s. 314 .

20 Kleine Anfrage der Abgeordneten Annalena Baerbock, Oliver Krischer, Manuel Sarrazi u.a. der Fraktion Bündnis 90/Die Grünen, Berlin, 6.2.2015, www.bmwi.de/Redaktion/ DE/Parlamentarische-Anfragen/2015/18-3817-position-der-bundesregierung-zu-denplaenen-ueber-eine-energieunion-und-zur-mitteilung-der-eu-kom-eine-investitionsoffensive-fuer-europa.pdf?_blob=publicationFile\&v=5 (dostęp: 25.04.2018).

21 B. Molo, Bezpieczeństwo zaopatrzenia..., s. 48-53. 
energetyczną. Zagadnienia włączone do koncepcji unii energetycznej dotyczyły zatem: efektywności energetycznej, ochrony klimatu, rozwoju odnawialnych źródeł energii, wspierania konkurencyjności i rozwoju nowych technologii oraz budowy wspólnego rynku energii ${ }^{22}$.

Moment, w którym została zaprezentowana formuła unii energetycznej, był szczególny, ponieważ zostały wówczas uzgodnione cele energetyczne i klimatyczne dla Unii Europejskiej do 2030 r., dobiegała końca kadencja komisji José Barroso, a nowo wybrana komisja pod przewodnictwem JeanClaude'a Junckera musiała przedstawić swoje założenia i priorytety na czas rozpoczynającej się kadencji. Wykorzystanie nośnej idei przez przewodniczącego Junckera znalazło odzwierciedlenie w utworzeniu nowego stanowiska wiceprzewodniczącego Komisji ds. unii energetycznej, które objął Maroš Šefčovič. Dodatkowo Donald Tusk został wybrany na stanowisko Przewodniczącego Rady Europejskiej, co mogło sugerować, że będzie się on starał utrzymać koncepcję unii energetycznej na liście priorytetów na forum $\mathrm{UE}^{23}$.

\section{Wyzwania unii energetycznej a koncepcja Energiewende}

Z przytoczonej definicji unii energetycznej wynikają bezpośrednio wyzwania dla całej UE, polegające na tym, aby skutecznie i efektywnie wdrożyć założenia i mechanizmy tej koncepcji. Jedno z wyzwań stanowi zagadnienie leżące u podstaw unii energetycznej, czyli zapewnienie bezpieczeństwa dostaw, szczególnie w odniesieniu do relacji z Rosją. Drugie wyzwanie odnosi się do renacjonalizacji energetyki i polityki przeciwdziałania zmianom klimatu w Unii Europejskiej. W momencie narodzin projektu unii energetycznej chodziło o nawiązanie do malejącego znaczenia takich instrumentów, jak handel emisjami czy transgraniczny handel energią. Wówczas państwa członkowskie zdecydowanie większy nacisk kładły na rozwój wewnętrznych systemów energetycznych, tj. rozbudowę instalacji OZE i infrastruktury. Po trzecie, wyzwaniem jest zrównoważona transformacja systemu energetycznego, którą rozumie się jako transformację sektora energetycznego i przejście na odnawialne źródła energii. Po czwarte, wzrost efektywności energetycznej, który ma skutkować zmniejszaniem zapotrzebowania na energię. Po piąte, dążenie do zapewnienia konkurencyjności Europy w przyszłości na globalnym rynku energii ${ }^{24}$.

22 G. Zachmann, The European Energy Union: Slogan or an Important Step towards Integration?, Friedrich Ebert Stiftung, Bonn 2015, s. 2.

23 Ibidem, s. 3.

24 Ibidem. 
Tak ogólnie nakreślone wyzwania obejmują liczne szczegółowe zagadnienia wymagające regulacji, rozwoju i wsparcia. Dlatego też w 2015 r. Komisja Europejska zaprezentowała trzy fundamentalne dokumenty, składające się na ,pakiet" unii energetycznej:

1) ramową strategię, która obejmuje zarówno cele, jak i kierunki rozwoju unii energetycznej;

2) unijną wizję porozumienia klimatycznego z Paryża z 2015 r.;

3) plan rozbudowy międzysystemowej zdolności przesyłu energii elektrycznej na poziomie $10 \%$ do $2020 \mathrm{r}^{25}$

$\mathrm{Z}$ pakietu unii energetycznej wyłania się wiele działań, które w efekcie mają zapewnić niedrogą, bezpieczną i zrównoważoną energię w Unii Europejskiej. Działania te zostały pogrupowane w pięciu dziedzinach ${ }^{26}$ :

1) bezpieczeństwo energetyczne, solidarność i zaufanie;

2) w pełni zintegrowany europejski rynek energii;

3) efektywność energetyczna jako środek do zmniejszania zapotrzebowania na energię;

4) redukcja poziomu emisji $\mathrm{CO}_{2} \mathrm{w}$ europejskiej gospodarce;

5) badania naukowe, innowacje i konkurencyjnośćc ${ }^{27}$.

W ramach pierwszej grupy, dążeniem jest dywersyfikacja kierunków dostaw i dostawców konwencjonalnych nośników energii oraz źródeł energii, czyli rozbudowa instalacji OZE. Takie działania mają na celu zapewnienie pewnych dostaw energii oraz zmniejszenie podatności państw Unii Europejskiej na zewnętrzne kryzysy energetyczne. Grupa działań, obejmująca zagadnienia związane $\mathrm{z}$ wewnętrznym rynkiem energii, odnosi się do takich kwestii, jak rozbudowa sieci połączeń międzysystemowych, uzupełnienie brakujących regulacji prawnych, ujednolicenie polityk energetycznych państw członkowskich i pogłębienie ich współpracy na tym polu oraz ułatwienie obywatelom wyboru dostawcy energii. Z kolei grupa działań nawiązująca do efektywności energetycznej zakłada jej podniesienie jej poziomu o przynajmniej 27\% do 2030 r., szczególnie w obszarze budownictwa i transportu. Czwarta grupa działań, nakierowana na dekarbonizację gospodarek w ramach

25 Pakiet dotyczacy unii energetycznej. Strategia ramowa na rzecz stabilnej unii energetycznej opartej na przyszłościowej polityce $w$ dziedzinie klimatu, Bruksela, 25.2.2015, s. 4, http://eur-lex.europa.eu/resource.html?uri=cellar:1bd46c90-bdd4-11e4-bbe1-01aa75ed71a1.0007.02/ DOC_1\&format=PDF (dostęp: 25.04.2018).

26 Unia energetyczna dla Europy, oficjalna strona Rady UE i Rady Europejskiej, www. consilium.europa.eu/pl/policies/energy-union (dostęp: 25.04.2018).

27 G. Zachmann, The European Energy..., s. 3. 
UE, oparta jest na polityce walki ze zmianami klimatycznymi. W związ$\mathrm{ku}$ z tym przyjęto założenie zmniejszenia emisji $\mathrm{CO}_{2}$ o przynajmniej $40 \%$ do 2030 r. w stosunku do 1990 r. Ostatnia grupa dotyczy budowy pozycji UE jako światowego lidera w zakresie nowych technologii OZE i powiązanych $\mathrm{z}$ nimi elementów, jak np. inteligentne sieci czy transport ekologiczny ${ }^{28}$.

Zasadniczym problemem jest rozbieżność interesów poszczególnych członków Unii, wynikająca z dalece odmiennych uwarunkowań, w jakich te państwa się znajdują i w jakich dotychczas formułowały wewnętrzną politykę energetyczną. Państwa członkowskie charakteryzuje różny stopień zależności energetycznej i samowystarczalności. Niemcy stoją na stanowisku, w którym nie są odosobnione, że do utworzenia unii energetycznej potrzebna jest spójna strategia. $Z$ tego względu nie powinno się rozdzielać tych pięciu grup działań, stanowiących filary unii energetycznej, lecz traktować je spójnie, a aktywność w którymkolwiek filarze powinna być sprzężona i zgodna pozostały$\mathrm{mi}^{29}$. Równocześnie Niemcy postulują stworzenie systemu zarządzania unią energetyczną. Miałby to być mechanizm, który wymuszałby pewne działania na poszczególnych krajach, ale także wzmacniał rolę konsumentów energii i pobudzał inwestycje w sektorze energetycznym. Taki system zarządzania miałby stanowić przede wszystkim efektywne narzędzie do budowy unii energetycznej, implementacji jej celów oraz monitorowania procesu jej realizacji ${ }^{30}$.

Inną kwestią jest pełna integracja rynków energii w UE, która wciąż napotyka ograniczenia natury technicznej, np. w regionie Europy Środkowo-Wschodniej z powodu przeciążonych łączy oraz niedostatecznej integracji rynków w tym obszarze. Niemcom udało się stworzyć wspólny rynek energii z Austrią, który istniał 17 lat i był największym transgranicznym rynkiem w Europie. Dzięki dobrym połączeniom Niemiec z Europą Zachodnią i Północną, także Austria uzyskała szerokie możliwości wymiany energii na znacznie większym obszarze ${ }^{31}$. Tę współpracę określano jako model dla przyszłej unii energetycznej i przykład spójnej kooperacji państw na polu energetycznym. Faktycznie jednak niemiecko-austriacka współpraca miała charakter wyłącznie bilateralny, bez uwzględniania interesów państw trzecich, co w przypadku przesyłu energii skutkowało tzw. kołowymi przepływami

28 B. Molo, Bezpieczeństwo zaopatrzenia..., s. 48-53.

29 Ibidem, s. 53.

30 J. Janikowski, S. Tokarski, Czy zarządzać unia energetyczna tak jak Wspólnota Węgla $i$ Stali?, „Polska Energia” grudzień 2015, www.cire.pl/pokaz-pdf-\%252Fpliki\%252F2\%252F10713uniaenergetyczna.pdf (dostęp: 25.04.2018).

31 Energy Policies of IEA Countries: Austria. 2014 Review. OECD/IEA, Paryż 2014, s. 148. 
energii elektrycznej, które destabilizowały system przesyłowy państw sąsiedzkich, w tym Polski. Powodem tej sytuacji były niewystarczające moce transmisyjne połączenia niemiecko-austriackiego, w wyniku czego energia elektryczna była przesyłana do Austrii przez Polskę i Czechy ${ }^{32}$. Wskutek interwencji polskiego Urzędu Regulacji Energetyki, Agencja ds. Współpracy Organów Regulacji Energetyki (Agency for the Cooperation of Energy Regulators) wydała we wrześniu 2015 r. opinię ${ }^{33}$, w której zaleciła rozdzielenie niemiecko-austriackiej strefy wymiany handlowej. Chocież opinia ta nie była wiążąca prawnie, Austria i Niemcy zobowiązały się do wprowadzenia procedur zarządzania ograniczeniami w przesyle ${ }^{34}$, a dalej rozdzielenia wspólnej strefy handlowej, co nastąpiło w $2018 \mathrm{r}$.

Eksperyment współpracy regionalnej nie zdał zatem egzaminu, ale wskazał na ważny element takiej kooperacji - konieczność zapewniania odpowiedniej infrastruktury dla przesyłu energii tak, aby odbywało się to bez szkody dla innych państw. Niemcy zdają sobie sprawę z konieczności zapobiegania przepływom kołowym, co stanowi dla nich wyzwanie tak w wymiarze wewnętrznym, jak i transgranicznym ${ }^{35}$. W trzecim raporcie dotyczącym stanu unii energetycznej potwierdzono, że bez dostosowania infrastruktury do wymogów przyszłego systemu energetycznego jego transformacja nie będzie możliwa. Tym bardziej że infrastruktura energetyczna, transportowa oraz telekomunikacyjna są coraz silnej ze sobą powiązane wraz z rozwojem innowacyjnych technologii, ich popularyzacją oraz stopniem digitalizacji. Sieci lokalne zyskują w życiu codziennym obywateli Unii Europejskiej coraz większe znacznie ze względu na elektromobilność, zdecentralizowaną produkcję energii elektrycznej oraz obciążenia sieci ${ }^{36}$.

32 ACER $w$ swojej opinii przyznat racje polskiemu regulatorowi, URE, 24.9.2015, www. ure.gov.pl/pl/urzad/wspolpraca-miedzynarod/6259,ACER-w-swojej-opinii-przyznal-rac je-polskiemu-regulatorowi.html (dostęp: 20.05.2018).

33 ACER Opinion 09-2015 on the compliance of NRAs' decision approving methods of cross-border capacity allocation in the CEE region, www.acer.europa.eu/Official_documents/Acts_of_the_Agency/Opinions/Opinions/ACER\%20Opinion\%2009-2015.pdf (dostęp: 20.05.2018).

34 Agentur für die Zusammenarbeit der Energieregulierungsbehörden empfiehlt Engpassmanagement an der deutsch-österreichischen Grenze, Bundesnetzagentur, 23.9.2015, www. bundesnetzagentur.de/cln_1432/SharedDocs/Pressemitteilungen/DE/2015/150923_GemeinsamePM.html?nn=265778 (dostęp: 20.05.2018).

35 Energieunion der EU: Netzausbau in Deutschland bleibt eine Herausforderung, Europäisches Informations-Zentrum (EIZ) Niedersachsen, 30.11.2017, www.eiz-niedersachsen. de/energieunion-der-eu-netzausbau-in-deutschland-bleibt-eine-herausforderung (dostęp: 20.05.2018).

36 Ibidem. 
Główne wyzwania unii energetycznej są zagadnieniami, które przyjęte zostały przez Niemcy już wcześniej, wraz z pojawieniem się i zdefiniowaniem polityki Energiewende, czyli transformacji energetycznej prowadzącej w stronę niskoemisyjnej gospodarki, opartej na nowoczesnych technologiach i odnawialnych źródłach energii, które mają zastąpić tradycyjne nośniki energii, w szczególności węgiel. Jako że cała koncepcja niemieckiej polityki transformacji energetycznej opiera się na uwzględnianiu wymogów ochrony środowiska, stąd kwestie związane z polityką energetyczną są w Niemczech ściśle powiązane $\mathrm{z}$ celami klimatycznymi ${ }^{37}$. Ze względu na znaczenie Niemiec w Europie, co jest związane z ich wielkością i siłą gospodarki, a także z powodu dużych ambicji przewodnictwa w transformacji energetycznej w państwie tym uważa się, że jego stosunek do unii energetycznej oraz działania będą kluczowe dla wdrażania tych koncepcji ${ }^{38}$.

W tym kontekście, zdaniem Niemiec, istotne jest, aby zostały opracowane bodźce, dzięki którym będą mogły być realizowane ambitne cele narodowe odnoszące się do rozbudowy instalacji OZE i podnoszenia efektywności energetycznej. Niemcy stoją na stanowisku, że efektywność energetyczna stanowi integralną część koncepcji unii energetycznej. Efektywność energetyczna oznacza, że przy mniejszym zużyciu energii osiąga się ten sam efekt, np. w produkcji przemysłowej. Zmniejszanie zużycia energii wiąże się z mniejszym wykorzystaniem surowców, a więc docelowo sprowadza się do redukcji ich importu ${ }^{39}$. Znamienne jest jednak, że w podjętych staraniach o dotację z Europejskiego Funduszu Inwestycji Strategicznych na inwestycje energetyczne ani jeden z przedstawionych projektów nie został przewidziany na zagadnienia związane $\mathrm{z}$ efektywnością energetyczną ${ }^{40}$. Tego rodzaju podejście, nieadekwatne do politycznych deklaracji, powoduje pytania na temat faktycznych możliwości wdrażania efektywności energetycznej, przy wykorzystaniu aktualnie dostępnych technologii, w obliczu dążeń do rozwoju gospodarczego i budowy silnego przemysłu.

W Niemczech często powtarzane są opinie, że cele transformacji energetycznej możliwe są do osiągnięcia tylko wspólnotowo, w ramach całej Unii. W niedługim czasie po przedstawieniu na forum unijnym koncepcji

37 A. Łada, M. Skłodowska, M. Szczepanik, Ł. Wenerski, Unia energetyczna.., s. 79-80.

38 G. Zachmann, The European Energy..., s. 4.

39 B. Molo, Bezpieczeństwo zaopatrzenia..., s. 48-55.

40 L. Bergamaschi, J. Gaventa, I. Holmes, Effektive und Nachhaltige Investitionen für Europas Klima- und Energieunion, April 2015, s. 4-5, www.e3g.org/docs/E3G_EFSI_Kurzstudie_Auswahlkriterien_April_2015.pdf(dostęp: 20.05.2018). 
unii energetycznej, Niemcy opracowały na jej temat non-paper, w którym podkreślono znaczenie powiązania jej z progresywnym rozwojem polityki klimatycznej, jak również agendą wzrostu i tworzeniem nowych miejsc pracy. Zasadniczym elementem unii energetycznej, w opinii rządu niemieckiego, powinno być zapewnienie efektywności energetycznej i dekarbonizacja, a zatem realizacja celów klimatycznych do $2030 \mathrm{r} .{ }^{41}$ Wspólnymi siłami Europa jest w stanie wesprzeć niemiecki wysiłek implementacji polityki Energiewende, a równocześnie samej rozwinąć się w tym zakresie. Unia energetyczna to platforma, która może pomóc $\mathrm{w}$ transferze promowanych przez Niemcy wartości i idei stojących za Energiewende na płaszczyznę europejską ${ }^{42}$. Takie podejście rodzi jednak wątpliwości, czy unia energetyczna nie jest traktowana przez Niemcy instrumentalnie do rozszerzania swoich wpływów na inne państwa członkowskie w celu realizacji własnych interesów gospodarczych i zdobywaniu konkurencyjnej przewagi na arenie międzynarodowej.

Podejście do unii energetycznej większości środowisk w Niemczech jest zasadniczo takie samo, jak do koncepcji Energiewende i powszechnie panuje w tym temacie zgoda. W odniesieniu do polityki energetycznej organizacje niemieckie, działające na rzecz ochrony środowiska, traktują powiązanie jej z polityką klimatyczną jako najważniejszy warunek rozwoju dalszych działań na tym polu. W ten sposób definiują bezpieczeństwo energetyczne jako stan, kiedy wszyscy będą dążyć do osiągnięcia celów klimatycznych, czyli zwiększać wykorzystanie OZE i poziom efektywności energetycznej. Stąd też pojawiały się w Niemczech opinie, odnoszące się krytycznie do koncepcji unii energetycznej w jej pierwotnym kształcie, ponieważ w zbyt dużym stopniu koncentrowano się na konwencjonalnych nośnikach energii. Popieranie unii energetycznej w tej formie było odbierane jako kwestionowanie celów klimatycznych. Tymczasem w niemieckim rozumieniu rozwój OZE powinien stanowić kluczowy element projektu unii energetycznej ${ }^{43}$.

\section{Wdrażanie unii energetycznej}

Sam projekt unii energetycznej, czyli w ogólnym rozumieniu dążenie do ujednolicenia polityki energetycznej w Unii Europejskiej, zyskał powszechną

41 A. Łada, M. Skłodowska, M. Szczepanik, Ł. Wenerski, Unia energetyczna..., s. 79.

42 G. Zachmann, Keine Energiewende ohne Energieunion, „Frankfurter Allgemeine Zeitung" 8 VI 2016, www.vernunftkraft-hessen.de/wordpress/wp-content/uploads/2016/06/ Dokument-2.pdf (dostęp: 25.04.2018).

43 A. Łada, M. Skłodowska, M. Szczepanik, Ł. Wenerski, Unia energetyczna..., s. 79-80. 
aprobatę państw członkowskich. Zastrzeżenia dotyczyły bardziej szczegółowych zagadnień i kwestii związanych z doprecyzowaniem pojęcia „unii energetycznej”. Dzieje się tak, ponieważ państwa członkowskie UE różni podejście do kwestii polityki energetycznej i pojmowanie występujących w jej ramach zagrożeń ze względu na różne warunki geopolityczne. Państwa te nie charakteryzują się tożsamym podejściem do Rosji jako kontrahenta, który w Europie Wschodniej jest uznawany za niewiarygodnego, podczas gdy Europa Zachodnia prezentuje odmienne stanowisko. Ze względu na warunki naturalne i dostępność surowców energetycznych, państwa europejskie w różny sposób ukształtowały swoje systemy energetyczne. Państwa członkowskie UE różnią się w poglądach na to, jaki powinien być ich udział w europejskiej produkcji energii z OZE oraz stopień podnoszenia efektywności energetycznej, a także co do kształtu wewnętrznego rynku energii ${ }^{44}$. Siła gospodarki zdeterminowała też poziom rozwoju infrastruktury energetycznej w państwach, w szeroko pojętym rozumieniu obejmującym nie tylko jednostki produkcyjne i sieci przesyłowe, ale również zaplecze naukowo-przemysłowe.

Powyżej zwrócono uwagę na odmienny stosunek państw członkowskich UE do Rosji, która jest głównym dostawcą ropy naftowej i gazu ziemnego do Unii. Koncepcja unii energetycznej była inspirowana działaniami Rosji polegającymi na tzw. szantażu energetycznym, czyli wykorzystywaniu przewagi ekonomicznej jako dostawcy do wywarcia presji politycznej. Tymczasem w niemieckiej perspektywie Rosja nie jest niepewnym kontrahentem, ale partnerem do współpracy opartej na obustronnych zależnościach. Z tego powodu Niemcy odmiennie definiują pojęcie bezpieczeństwa energetycznego niż np. Polska. W optyce niemieckiej zapewnienie ciągłości dostaw energii odnosi się do wymiaru technicznego, a zatem do sprawnej infrastruktury, stabilnej produkcji energii i elastycznego zarządzania energią. Przyjmuje się założenie labilności produkcji energii z OZE, w wyniku którego istnieje ryzyko wystąpienia przerw w dostawach energii. Jednakże nie zakłada się braku dostaw energii czy też jej nośnika ze źródeł zewnętrznych. Kwestia zapewnienia bezpieczeństwa energetycznego w Niemczech nie jest zatem rozpatrywana ściśle w wymiarze geopolitycznym, co przekłada się na stosunek do unii energetycznej oraz rozumienie celu jej budowy ${ }^{45}$.

$\mathrm{Z}$ tego bezpośrednio wynika, dlaczego do projektu unii energetycznej, przedstawionego przez Donalda Tuska, szybko zostały włączone idee ochrony

44 G. Zachmann, Keine Energiewende...

45 A. Łada, M. Skłodowska, M. Szczepanik, Ł. Wenerski, Unia energetyczna..., s. 60. 
środowiska i klimatu, czyli coraz bardziej popularnego trendu transformacji sektora energetycznego w stronę niskoemisyjności, dekarbonizacji, wysokiej wydajności przy jednoczesnym zmniejszaniu energochłonności, rozbudowy instalacji OZE oraz kreowaniu świadomych i aktywnych energetycznie obywateli. W związku z silnym naciskiem na kwestie wdrażania transformacji energetycznej, można się było spotkać z zarzutem, że ,pomysł na unię energetyczną przekształcił się w unię klimatyczną" ${ }^{46}$. W tym aspekcie Niemcy niewątpliwie odgrywają istotną rolę w Unii Europejskiej. Niemniej jednak, oprócz tematyki energetyczno-klimatycznej, definicję unii energetycznej rozszerzono także o kwestie gospodarcze. Chodzi o modernizację europejskiej gospodarki w kierunku dążeń do zmniejszania jej emisyjności i podnoszenie efektywności energetycznej i surowcowej ${ }^{47}$.

Równocześnie dzięki unii energetycznej, zgodnie z założeniami, utrzymane mają być dążenia do rozwoju europejskiej gospodarki i wzrostu jej poziomu innowacyjności tak, aby wzmacniać konkurencyjność gospodarczą Unii Europejskiej w skali światowej. Rynek OZE i związane z nimi nowe technologie przedstawiają spory potencjał rozwojowy do budowy silnej gospodarki. UE ma na tym polu określone doświadczenia, a zatem wykorzystując swoje polityki zewnętrzne, może budować partnerstwa z innymi państwami, aby globalnie promować gospodarkę niskoemisyjną. W ten sposób dąży do objęcia pozycji światowego lidera transformacji energetycznej gospodarki światowej ${ }^{48}$. Globalne aspiracje UE determinują konieczność utworzenia silnego wymiaru zewnętrznego, stąd do projektu unii energetycznej włączono wzmocnioną dyplomację energetyczną. Celem tej dyplomacji jest wzrost bezpieczeństwa dostaw energii, zwiększenie popularności technologii niskoemisyjnych poza granicami Wspólnoty, a także podnoszenie konkurencyjności unijnego przemysłu ${ }^{49}$. Takie podejście może być rozumiane jako swego rodzaju misja UE, polegająca na promocji czystej energii w celu zapewnienia ochrony środowiska i klimatu. Jednocześnie jest to również wzmocnienie pozycji UE w skali globalnej, realizacja długoterminowych interesów gospodarczych i rozszerzanie wpływów politycznych poprzez popularyzację swoich koncepcji i idei rozwoju.

46 Raport z debaty Perspektywa rynków energii, a unia energetyczna, 20.05.2015, „Polityka”, Społeczna Rada ds. Zrównoważonego Rozwoju Energetyki, Warszawa.

47 Drugie sprawozdanie na temat stanu unii energetycznej, $\operatorname{COM(2017)~} 53$ final, Bruksela, dnia 1.02.2017, s. 2, http://eur-lex.europa.eu/resource.html?uri=cellar:95faa4c3-ec57-11e6-ad7c-01aa75ed71a1.0021.02/DOC_1\&format=PDF (dostęp: 20.05.2018).

48 Ibidem, s. 14.

49 Ibidem, s. 3. 
W związku z tym czynniki dla rozwoju transformacji systemu energetycznego w Europie w ramach unii energetycznej obejmują:

1) zrównoważony rozwój gospodarczy,

2) solidarność i zaufanie państw członkowskich,

3) strategiczne działania na skalę globalną,

4) wypracowanie „odporności” europejskiego systemu energetycznego

(tj. zapewnienie nieprzerwanych dostaw energii ${ }^{50}$.

Tak określona transformacja energetyczna, polegająca na budowaniu bezpiecznego i zrównoważonego systemu energetycznego, determinuje wiele inwestycji. Na wdrażanie celów w obszarze klimatu i energii do 2030 r., jak oszacowano, w latach 2020-2030 konieczne byłyby inwestycje o wartości ok. 379 mld EUR rocznie ${ }^{51}$. W latach 2014-2020 wsparcie to wynosi łącznie ok. 98 mld EUR w formie współfinansowania krajowego ze środków publicznych i prywatnych. Zasadniczą rolę w tym finansowaniu ogrywa Europejski Fundusz na rzecz Inwestycji Strategicznych (EFIS), ale równie istotne są także Europejskie Fundusze Strukturalne i Inwestycyjne (EFSI) ${ }^{52}$. Z Europejskiego Funduszu Inwestycji Strategicznych chcą skorzystać Niemcy, przeznaczając kwotę 15,9 mld EUR na projekty związane z energetycznym wymiarem infrastruktury transportowej, szczególnie lotnisk i transportu drogowego. Infrastruktura transportowa o najwyższym poziomie szkodliwych emisji znajduje się bowiem na drugiej pozycji na liście priorytetów związanych z projektami o wymiarze energetycznym, zaraz po branży IT. Trwała infrastruktura transportowa, np. szynowa, stanowi 4\% wydatków tej sumy. Kwota 9,1 mld EUR ma zostać przeznaczona na OZE, a 5,2 mld EUR na sieci przesyłowe. Na budowę terminala LNG przewidziano 1 mld EUR. Warto przy tym nadmienić, że w ostatnich 10 latach niemieckie zużycie gazu ziemnego spadło o $15 \%{ }^{53}$.

Rozbudowa instalacji odnawialnych źródeł energii pociąga za sobą konieczność rozwoju i dostosowywania potrzebnej infrastruktury nie tylko wewnątrzkrajowej, ale również transgranicznej. Jest to związane z koniecznością równoważenia poziomu energii elektrycznej produkowanej z OZE, ze względu na jego zależność od pogody, za pomocą konwencjonalnych nośników energii $^{54}$. Tworzenie elektroenergetycznych połączeń międzysystemowych ma

50 S. Andoura, J.A. Vinois, From the European..., s. 128.

51 Drugie sprawozdanie..., s. 12.

52 Ibidem.

53 L. Bergamaschi, J. Gaventa, I. Holmes, Effektive..., s. 4-5.

54 A. Łada, M. Skłodowska, M. Szczepanik, Ł. Wenerski, Unia energetyczna..., s. 61. 
zapewniać optymalne wykorzystanie zasobów odnawialnych, bezpieczeństwo dostaw oraz integrację rynku. Brak infrastruktury lub niewystarczające jej wykorzystanie w znacznym stopniu ograniczają realizację celów unii energetycznej. Istotnym elementem infrastruktury fizycznej jest zapewnienie odpowiedniego zarządzania połączeniami międzysystemowymi. W tym celu prowadzi się m.in. działania na rzecz synchronizacji sieci energetycznych państw bałtyckich z europejskimi systemami energetycznymi ${ }^{55}$.

Transformacja energetyczna, w przewidywaniach niektórych ośrodków badawczych, wymaga przeznaczenia ok. 200 mld EUR rocznie na inwestycje w efektywność energetyczną, OZE, sieci przesyłowe oraz inne długoterminowe technologie, które będą wspierały tym samym tworzenie unii energetycznej, jak podkreśla się w Niemczech - przyjaznej klimatowi ${ }^{56}$. Niemcy w celach dotyczących unii energetycznej przede wszystkim podkreślają wagę ochrony klimatu i środowiska, w mniejszym stopniu kwestię bezpieczeństwa energetycznego. Daje się zauważyć, że unia energetyczna w niemieckim rozumieniu służy realizacji transformacji energetycznej na skalę europejską, a zatem jest narzędziem Energiewende.

Zdaniem Niemiec, w projekcie unii energetycznej powinno się skupić na konstruowaniu warunków do inwestycji w innowacyjne technologie niskoemisyjne i o wysokiej efektywności energetycznej, w tym w szczególności OZE. Działania te mają służyć budowie konkurencyjnego przemysłu europejskiego w przyszłości ${ }^{57}$. Dofinansowanie określonych działań na rynku obarczone jest jednak pewnym ryzykiem. Produkcja na dużą skalę subsydiowanej energii spowodowała, że został zachwiany mechanizm działania na rynku hurtowym. Energia z OZE nie tylko jest subsydiowana, ale również ma priorytet $\mathrm{w}$ sieci, $\mathrm{w}$ związku z tym energii wyprodukowanej ze źródeł konwencjonalnych trudno jest konkurować $\mathrm{z}$,zieloną” energią na wolnorynkowych zasadach. Jednocześnie OZE, ze względu na labilność produkcji, wciąż muszą być uzupełniane przez tradycyjne elektrownie ${ }^{58}$.

Niektórzy eksperci zauważają, że problemem leżącym u podstaw wsparcia projektów w sektorze energetycznym przez UE są błędne założenia dotyczące przyszłego popytu. Na przykład w raporcie ewaluacyjnym dotyczącym projektu „Łącząc Europę” (Connecting Europe Facility) przyjęto wzrost zapotrzebowania na gaz o 70\% w stosunku do wartości, którą Komisja Europejska

55 Drugie sprawozdanie..., s. 11.

56 L. Bergamaschi, J. Gaventa, I. Holmes, Effektive..., s. 1.

57 B. Molo, Bezpieczeństwo zaopatrzenia..., s. 53.

58 A. Łada, M. Skłodowska, M. Szczepanik, Ł. Wenerski, Unia energetyczna.., s. 13. 
prognozuje przy ustanawianiu celów dla efektywności energetycznej w UE. Tego typu podejście przyczynia się do wsparcia budowy gazociągów i terminali LNG, które w obliczu zmniejszającego się zapotrzebowania na gaz ziemny (spadek o 9\% w ciągu ostatnich 10 lat) nie będą w pełni wykorzystywane, natomiast będą wymagały konserwacji ${ }^{59}$.

Unia energetyczna ma służyć również stworzeniu jednolitego rynku energii w Unii Europejskiej. Obecnie dominujący model rynku w państwach członkowskich UE składa się z centralnych elektrowni na paliwa konwencjonalne, najczęściej węgiel lub gaz, i będzie on powoli, ale radykalnie przekształcany - zgodnie z założeniami - w stronę modelu ze zdecentralizowaną i labilną produkcją energii ze źródeł odnawialnych. Zmiany te oznaczają przejście na krótkoterminowe kontrakty oraz coraz więcej transgranicznego przesyłu energii. Jednolity rynek energii oznacza połączenie nie tylko rynków hurtowych, ale także detalicznych, co pociąga za sobą konieczność ujednolicania polityki energetycznej przez wszystkie państwa członkowskie. Szczególnym wyzwaniem na tym polu jest obszar IT do koordynacji całego systemu. Unia energetyczna miałaby zatem łączyć różne obszary gospodarcze i polityczne, które dotychczas funkcjonowały osobno ${ }^{60}$. W ramach wspólnego rynku energii głównymi beneficjentami tego rozwiązania mają być końcowi odbiorcy energii.

Warunkiem budowy wspólnego rynku energii jest ujednolicenie reguł dla produkcji energii na rynkach narodowych. Pociąga to za sobą konieczność harmonizowania systemów wsparcia dla OZE. W przeciwnym wypadku istnieje ryzyko, że generowanie rynków regionalnych doprowadzi do zaburzeń konkurencji i sztucznego kreowania zwycięzców, korzystających na dużą skalę z dopłat, szczególnie w najbogatszych państwach Unii ${ }^{61}$. W odniesieniu do kwestii regulacji, oprócz konieczności implementacji nowych przepisów w szczególności na nowych obszarach unijnej działalności, jednocześnie pojawia się zarzut o ich nadmiarze. Państwa UE nie nadążają z implementacją licznych przepisów dotyczących pakietu energetyczno-klimatycznego i trzeciego pakietu energetycznego, w związku z czym nastąpił masowy wzrost postępowań przed Trybunałem Sprawiedliwości Unii Europejskiej ${ }^{62}$.

59 L. Bergamaschi, J. Gaventa, I. Holmes, Effektive..., s. 4-5.

60 Energieunion: Binnenmarkt im Kommen, „Power Letter” 2015/2016, s. 21-24, www. power-solution.eu/wp-content/uploads/Jahreshefte/powerletter-2015_2016.pdf (dostęp: 20.05.2018).

61 J. Janikowski, S. Tokarski, Czy zarządzać...

62 A. Łada, M. Skłodowska, M. Szczepanik, Ł. Wenerski, Unia energetyczna..., s. 14. 
Konsekwencje przeregulowania są dużo bardziej rozległe i w efekcie grożą paraliżem implementacji określonych celów.

Niemcy w pełni popierają budowę wewnętrznego rynku energii elektrycznej oraz gazu w Unii Europejskiej, uważają ten element za centralny punkt projektu unii energetycznej. Utworzenie wewnątrzunijnego rynku energii pozwoli na osiągnięcie konkurencyjnych cen energii, zintegrowanie OZE z rynkiem, podniesienie bezpieczeństwa energetycznego, jak też i efektywności energetycznej. Ze względu na aspekt bezpieczeństwa energetycznego, niemiecki rząd uważa, że priorytetem powinny być projekty infrastrukturalne. Pozwoliłyby one także zakończyć lub przynajmniej znacząco ograniczyć izolację energetyczną państw UE. Takie stanowisko niemieckiego rządu przedstawił ówczesny minister Sigmar Gabriel przy okazji spotkania ministrów gospodarki i energii państw członkowskich Unii Europejskiej, które odbyło się w marcu 2015 r. w Brukseli. Zwrócił on uwagę na potencjał unii energetycznej, który leży w szansie wzmocnienia Europy w obszarze energii oraz przyspieszenia integracji europejskiej ${ }^{63}$.

$\mathrm{Z}$ tego powodu, w wyniku niemieckiej inicjatywy, w czerwcu 2015 r. na posiedzeniu Rady Ministrów ds. Energetyki UE podpisano deklarację o współpracy regionalnej w zakresie bezpieczeństwa dostaw energii elektrycznej i przyspieszenia budowy europejskiego rynku energii (Joint Declaration for Regional Cooperation on Security of Electricity Supply in the Framework of the Internal Energy Market). Sygnatariusze uznali, że kwestia zapewnienia bezpieczeństwa dostaw energii elektrycznej ma być rozstrzygana na poziomie regionalnym, nie zaś narodowym. W dokumencie znalazły się także zobowiązania odnoszące się do polepszania koordynacji narodowych polityk energetycznych oraz bardziej efektywnego wykorzystania istniejącej sieci elektroenergetycznej, jak też ich rozbudowy w celu wspierania handlu energią elektryczną. Podkreślono także potrzebę wzmocnienia integracji OZE na narodowych rynkach ${ }^{64}$.

\section{Wnioski}

Unia energetyczna ma w praktyce realizować koncepcję bezpieczeństwa energetycznego na obszarze Unii Europejskiej. Projekt unii energetycznej łączy definicję bezpieczeństwa energetycznego, czyli zapewnienia pewnych

63 B. Molo, Bezpieczeństwo zaopatrzenia..., s. 53-55.

64 Ibidem, s. 54-55. 
i nieprzerwanych dostaw energii, z priorytetami polityki ochrony środowiska i klimatu, do których należy zmniejszenie zapotrzebowania na energię poprzez rozwijanie efektywności energetycznej, dekarbonizację gospodarki i obniżanie szkodliwych emisji, rozbudowę rynku wewnętrznego oraz infrastruktury, w szczególności OZE. Daje się zauważyć, że unia energetyczna raczej na nowo formułuje znane już rozwiązania, zadania i cele, niż ustanawia nowe ${ }^{65}$. Ma stanowić platformę zarządzającą, na której będą łączone już istniejące i rozwijane cele, oraz ma służyć ich upowszechnianiu i ujednolicaniu we wszystkich państwach $\mathrm{UE}^{66}$. Nowym elementem, który owa koncepcja wprowadza, jest położenie akcentu na bezpieczeństwo energetyczne, szczególnie uwzględniając okoliczności, w których została ona zaprezentowana na forum unijnym ${ }^{67}$.

W celu integracji wewnętrznego rynku energii elektrycznej między regionami Unii Europejskiej potrzebne są połączenia międzysystemowe. W kontekście dążeń do wzrostu produkcji energii z OZE, wraz z rozbudową sieci i systemu zarządzania nimi powinna następować rozbudowa magazynów energii. Unia energetyczna, poprzez działania i projekty przewidziane w jej ramach, ma być korzystna dla konsumentów energii. Rozbudowa sieci i infrastruktury energetycznej umożliwia zwiększenie decentralizacji i elastyczności w produkcji energii, wzrost konkurencji na rynku energii skutkujący spadkiem cen, wspieranie rynków mocy i magazynów energii mających podnosić pewność i bezpieczeństwo stałych dostaw energii ${ }^{68}$. Wspólny rynek pozwoli na wzmocnienie pozycji Unii Europejskiej oraz jej podmiotów jako stron w czasie rozmów negocjacyjnych. Utworzenie wewnątrzunijnego rynku gazu przy wsparciu odpowiednich mechanizmów zapewni UE silniejszą pozycję w negocjacjach handlowych wobec kontrahentów ${ }^{69}$. Aby zapewnić sobie silną pozycję na globalnym rynku energii i technologii OZE, Unia Europejska stawia sobie za cel w pierwszej kolejności podołanie wyzwaniom idącym w parze $\mathrm{z}$ transformacją energetyczną i budową własnej

65 J. Ecke, N. Herrmann, Perspektiven einer europäischen Energieunion für Verbraucherinnen und Verbraucher, s. 23, https://enervis.de/wp-content/uploads/2018/01/12340.pdf (dostęp: 20.05.2018).

66 K. Umpfenbach, Nach der Bundestagswahl: Worauf es für die deutsche Politik beim Energiepaket der EU ankommt, Heinrich-Böll-Stiftung, Berlin, Oktorber 2017, s. 4, www.boell.de/sites/default/files/nach_der_bundestagswahl-energiepaket_eu.pdf?dimension $1=$ division_eu (dostęp: 20.05 .2018$)$.

67 J. Ecke, N. Herrmann, Perspektiven...

68 Ibidem.

69 A. Łada, M. Skłodowska, M. Szczepanik, Ł. Wenerski, Unia energetyczna..., s. 75. 
niskoemisyjnej gospodarki. UE w swoich strategiach energetycznych, gospodarczych i rozwoju wyznacza ambitne cele, ich realizacja jednak rozbija się niejednokrotnie o zbyt daleko idące zróżnicowanie państw członkowskich, które zależy od ich indywidualnych uwarunkowań ${ }^{70}$.

Niemcy, jako silne gospodarczo i politycznie państwo członkowskie UE, popierają inicjatywę unii energetycznej, ale starają się nadać jej kształt zgodny z wykreowaną przez siebie polityką Energiewende i realizują tę koncepcję zgodnie z własnymi interesami gospodarczymi. Tak więc zdaniem rządu niemieckiego postulat ustanowienia mechanizmu wspólnych zakupów gazu ziemnego jest sprzeczny z zasadami wolnego rynku. Jednakże dokończenie procesu budowy wewnętrznego rynku energii i gazu w UE przyczyni się do wzmocnienia europejskiej pozycji negocjacyjnej w umowach handlowych z zewnętrznymi dostawcami ${ }^{71}$. Jakkolwiek więc Niemcy nie negują dążeń do wzmacniania bezpieczeństwa energetycznego, to jednak w sprawie unii energetycznej kładą nacisk głównie na transformację energetyczną, wskazując na potrzebę ochrony klimatu jako nadrzędny priorytet. Unia energetyczna jest, w rozumieniu niektórych niemieckich ośrodków badawczych, płaszczyzną organizacyjną dla energetyki przede wszystkim regionalnej i ma służyć głównie lokalnym inicjatywom, wspierając jednocześnie współpracę między państwami członkowskimi UE. Unia energetyczna powinna zatem służyć w niemieckim rozumieniu rozwiązaniami dla mniejszych obszarów, nie zaś stanowić powszechny konsensus dla wszystkich państw członkowskich, jakkolwiek nakreślane przez nią cele mają wymiar uniwersalny dla całej Unii ${ }^{72}$.

\section{Bibliografia}

ACER Opinion 09-2015 on the Compliance of NRAs' Decision Approving Methods of Crossborder Capacity Allocation in the CEE Region, www.acer.europa.eu/Official_documents/ Acts_of_the_Agency/Opinions/Opinions/ACER\%20Opinion\%2009-2015.pdf.

ACER w swojej opinii przyznat rację polskiemu regulatorowi, URE, 24.9.2015, www.ure.gov.pl/ pl/urzad/wspolpraca-miedzynarod/6259,ACER-w-swojej-opinii-przyznal-racje-polskiemu-regulatorowi.html.

Agentur für die Zusammenarbeit der Energieregulierungsbehörden empfiehlt Engpassmanagement an der deutsch-österreichischen Grenze, Bundesnetzagentur, 23.09.2015, www. bundesnetzagentur.de/cln_1432/SharedDocs/Pressemitteilungen/DE/2015/150923_GemeinsamePM.html?nn=265778.

70 Drugie sprawozdanie..., s. 12.

71 B. Molo, Bezpieczeństwo zaopatrzenia..., s. 53.

72 J. Ecke, N. Herrmann, Perspektiven... 
Andoura S., Vinois J.A., From the European Energy Community to the Energy Union. A Policy Proposal for the Short and the Long Term, „Studies \& Reports” 2015, nr 107, Jacques Delors Institute.

Bergamaschi L., Gaventa J., Holmes I., Effektive und Nachhaltige Investitionen für Europas Klima- und Energieunion, April 2015, s. 4-5, www.e3g.org/docs/E3G_EFSI_Kurzstudie Auswahlkriterien_April_2015.pdf.

Bieleń S., Erozja monocentryzmu w stosunkach międzynarodowych, w: P. Eberhardt (red.), Studia nad geopolityka XX wieku, „Prace Geograficzne” Warszawa 2013, nr 242.

Drugie sprawozdanie na temat stanu unii energetycznej, COM(2017) 53 final, Bruksela, dnia 1.02.2017, s. 2, http://eur-lex.europa.eu/resource.html?uri=cellar:95faa4c3-ec5711e6-ad7c-01aa75ed71a1.0021.02/DOC_1\&format=PDF.

Ecke J., Herrmann N., Perspektiven einer europäischen Energieunion für Verbraucherinnen und Verbraucher, https://enervis.de/wp-content/uploads/2018/01/12340.pdf.

Energieunion der EU: Netzausbau in Deutschland bleibt eine Herausforderung, Europäisches Informations-Zentrum (EIZ) Niedersachsen, 30.11.2017, www.eiz-niedersachsen.de/ energieunion-der-eu-netzausbau-in-deutschland-bleibt-eine-herausforderung/.

Energieunion: Binnenmarkt im Kommen, „Power Letter” 2015/16, www.power-solution.eu/ wp-content/uploads/Jahreshefte/powerletter-2015_2016.pdf.

Energy Policies of IEA Countries: Austria, 2014 Review, OECD/IEA. Paryż 2014.

EU Imports of Energy Products - Recent Developments, Eurostat, data extracted in October 2017, http://ec.europa.eu/eurostat/statistics-explained/pdfscache/46126.pdf.

Haliżak E., Ekonomiczny wymiar bezpieczeństwa narodowego i międzynarodowego, w: D.B. Bobrow, E. Haliżak, R. Zięba (red.), Bezpieczeństwo narodowe i międzynarodowe u schytku XX wieku, Wydawnictwo Naukowe „Scholar”, Warszawa 1997.

Haliżak E., Liberalna teoria polityki zagranicznej, w: E. Haliżak, R. Ożarowski, A. Wróbel (red.), Liberalizm i neoliberalizm $w$ badaniu polityki zagranicznej państwa $i$ gospodarki światowej, Rambler staraniem Polskiego Towarzystwa Stosunków Międzynarodowych, Warszawa 2016.

Janikowski J., Tokarski S., Czy zarządzać uniq energetyczna tak jak Wspólnota Węgla i Stali?, „Polska Energia”, grudzień 2015, www.cire.pl/pokaz-pdf-\%252Fpliki\%252F2\%252F10713uniaenergetyczna.pdf.

Kaczmarski M., Bezpieczeństwo energetyczne Unii Europejskiej, Wydawnictwa Akademickie i Profesjonalne, Warszawa 2010.

Kleine Anfrage der Abgeordneten Annalena Baerbock, Oliver Krischer, Manuel Sarrazi u.a. der Fraktion Bündnis 90/Die Grünen, Berlin, 6.02.2015, www.bmwi.de/Redaktion/ DE/Parlamentarische-Anfragen/2015/18-3817-position-der-bundesregierung-zu-denplaenen-ueber-eine-energieunion-und-zur-mitteilung-der-eu-kom-eine-investitionsoffensive-fuer-europa.pdf?_blob=publicationFile \&v $=5$.

Kucharska A., Energy Transition in Switzerland, w: M. Ruszel, T. Młynarski, A. Szurlej (red.), Energy Policy Transition: the Perspective of Different States, Ignacy Łukasiewicz Energy Policy Institute, Rzeszów 2017.

Łada A., Skłodowska M., Szczepanik M., Wenerski Ł., Unia energetyczna z perspektywy Francji, Niemiec, Polski i Wielkiej Brytanii, Instytut Spraw Publicznych, Warszawa 2015. Mazurkiewicz J., Bezpieczeństwo energetyczne Polski, „Polityka Energetyczna” 2008, t. 11, z. 1. Molo B., Bezpieczeństwo zaopatrzenia energetycznego Niemiec w kontekście unii energetycznej Unii Europejskiej, „Bezpieczeństwo - Teoria i Praktyka” 2016, nr 1, KSW, Kraków 2016. 
Pakiet dotyczacy unii energetycznej. Strategia ramowa na rzecz stabilnej unii energetycznej opartej na przyszlościowej polityce w dziedzinie klimatu, Bruksela, 25.2.2015, http://eur-lex. europa.eu/resource.html?uri=cellar:1bd46c90-bdd4-11e4-bbe1-01aa75ed71a1.0007.02/ DOC_1\&format=PDF.

Raport z debaty Perspektywa rynków energii, a unia energetyczna, 20.05.2015, „Polityka”, Społeczna Rada ds. Zrównoważonego Rozwoju Energetyki, Warszawa.

Ulatowski R., Geoekonomia surowców energetycznych, Rambler, Warszawa 2014.

Umpfenbach K., Nach der Bundestagswahl: Worauf es für die deutsche Politik beim Energiepaket der EU ankommt, Heinrich-Böll-Stiftung, Berlin, Oktorber 2017, s. 5, www.boell.de/sites/ default/files/nach_der_bundestagswahl-energiepaket_eu.pdf?dimension1=division_eu.

Unia energetyczna dla Europy, oficjalna strona Rady UE i Rady Europejskiej, www.consilium. europa.eu/pl/policies/energy-union/.

Wittpahl V., Digitalisierung. Bildung - Technik-Innovation, iit-Themenband, Springer, Berlin 2017.

Zachmann G., Keine Energiewende ohne Energieunion, „Frankfurter Allgemeine Zeitung”, 8 VI 2016, www.vernunftkraft-hessen.de/wordpress/wp-content/uploads/2016/06/Dokument-2.pdf.

Zachmann G., The European Energy Union: Slogan or an Important Step towards Integration?, Friedrich Ebert Stiftung, Bonn 2015.

Żukrowska K., Grącik M. (red.), Bezpieczeństwo międzynarodowe. Teoria i praktyka, Szkoła Główna Handlowa, Warszawa 2006. 